\title{
Stability of an octocoral-algal symbiosis over time and space
}

\author{
Tamar L. Goulet ${ }^{1,2, *}$, Mary Alice Coffroth ${ }^{1}$ \\ ${ }^{1}$ Department of Biological Sciences, State University of New York at Buffalo, 661 Hochstetter Hall, Buffalo, New York 14260, USA \\ ${ }^{2}$ Present address: Department of Biology, University of Mississippi, 524 Shoemaker Hall, Mississippi 38677, USA
}

\begin{abstract}
In symbiosis, 2 taxonomically different organisms co-exist, each pursuing their own agenda and yet, they are linked in one entity. A mutualistic symbiosis may break up if it is no longer beneficial to either one of the partners. Changing needs over time or changing environmental conditions may prompt symbiont switching. For example, corals may survive elevated temperatures by switching their algal symbionts. If switching occurs, the new combination of host and symbiont genotypes may perform better. Conversely, the partners may be fixed for life, with the degree to which the mutualism responds to changing selection pressures dictated by the existing partners. Understanding the genotypic dynamics of a mutualism is important for predicting the potential resilience of a mutualism over time and in the face of environmental perturbations. Although mutualisms tend to be characterized at the species level or higher, host-symbiont dynamics is an individual-level question, requiring individual-level analysis. We used multilocus DNA fingerprinting to examine long-term temporal and spatial symbiont change in the mutualism between the octocoral Plexaura kuna and its algal symbionts (zooxanthellae). We monitored zooxanthella genotypes within a colony for up to $10 \mathrm{yr}$, among $P$. kuna clonemates, across different habitats and in colonies transplanted to novel environments. In all instances, the prominent zooxanthella genotype within a $P$. kuna colony remained unchanged although zooxanthella genotypes varied among genetically distinct $P$. kuna colonies. Such tremendous temporal and spatial stability may occur in other coral hosts, influencing the reaction and survival of mutualisms during environmental change.
\end{abstract}

KEY WORDS: Symbiosis · Zooxanthellae $\cdot$ Corals $\cdot$ Plexaura kuna $\cdot$ Genotype $\cdot$ Multilocus DNA fingerprinting $\cdot$ Stability

Resale or republication not permitted without written consent of the publisher

\section{INTRODUCTION}

Coral reefs are typified and dominated by the mutualism between cnidarian hosts (e.g. stony corals, octocorals, sea anemones) and dinoflagellate symbionts (algae commonly called zooxanthellae). The algae receive the cnidarian's nitrogenous wastes, and one of the main benefits to the host is the translocation of photosynthetically fixed substances from the zooxanthellae (Muscatine \& Porter 1977). Coral reefs are affected by environmental perturbations such as elevated seawater temperatures and pathogens, which have both increased in the last few decades (Rosenberg \& Ben-Haim 2002). These perturbations often cause coral bleaching (i.e. the loss of zooxanthellae and/or zooxanthella pigments) (Glynn 1996).
The possibility of symbiont switching in coral-algal mutualisms has been raised to explain the potential adaptive value of coral bleaching (Buddemeier \& Fautin 1993, Ware et al. 1996). Under new environmental conditions, a specific mutualistic pair, consisting of an individual cnidarian genotype and its algal genotype(s), may not work well as a unit. If symbiont switching can occur, a new host-symbiont combination might perform better in the new environment. If the mutualistic unit is fixed, the cnidarian-zooxanthella genotypic combination will have to adapt as a unit to the new environment or perish. Understanding whether individual hosts can change their individual symbionts is therefore crucial for conservation approaches and for understanding the mutualisms as a whole. 
Until recently, zooxanthella identity remained elusive due to the paucity of differentiating morphological characteristics. Rowan \& Powers (Rowan 1991, Rowan \& Powers 1991, 1992), using sequence comparisons and restriction fragment length polymorphisms (RFLP) of DNA coding for small subunit ribosomal RNA (SSuRNA), provided a relatively easy and attainable division of zooxanthellae into genetically discernable groups termed clades. Since then, researchers have assigned zooxanthella cladal identity to symbionts in a wide variety of hosts such as stony corals (Darius et al. 1998, Baker 1999, Loh et al. 2001, Rodriguez-Lanetty et al. 2001, van Oppen et al. 2001, Diekmann et al. 2002, LaJeunesse 2002), octocorals (Carlos et al. 1999, Goulet 1999, LaJeunesse 2002, Santos et al. 2002, Goulet \& Coffroth 2003), sponges (Hill \& Wilcox 1998) and giant clams (Baillie et al. 2000b).

Using the cladal level of resolution, Rowan \& Knowlton (1995), Rowan et al. (1997), Baker (2001) and Toller et al. (2001a) documented that 10 coral species can host several zooxanthella clades simultaneously. Following environmental change, these corals displayed different zooxanthella clades (Rowan et al. 1997, Baker 2001, Toller et al. 2001b). It is unknown whether these clades were previously present but undetected because they were rare, or whether new clades entered the host from the environment (Toller et al. 2001b, Hoegh-Guldberg et al. 2002). Although the implication of zooxanthella cladal turnover in a changing environment is intriguing, in fact, such turnover appears to be the exception rather than the rule. The majority of cnidarians (168 of 199 species) host only 1 detectable zooxanthella clade (Rowan \& Powers 1991, Baker \& Rowan 1997, Billinghurst et al. 1997, Bythell et al. 1997, Wilcox 1997, Darius et al. 1998, Baker 1999, Goulet 1999, van Oppen et al. 2001, Diekmann et al. 2002), making cladal-level resolution not adequate for resolving the dynamics of zooxanthellae, either temporally or spatially, in the majority of these mutualisms. Additional genetic techniques have been utilized to elucidate variation within a clade (Baillie et al. 1998, 2000a,b, Carlos et al. 2000, LaJeunesse 2001, Santos et al. 2001); however, these techniques are still too coarse to examine the individual level association between a host genotype and its symbiont genotype(s). We therefore chose multilocus DNA fingerprinting to examine individual mutualisms. DNA fingerprinting of total genomic DNA resolves between genetically different individuals (Jeffreys et al. 1985a,b) and has been used for identifying distinct genotypes (Coffroth et al. 1992, Coffroth \& Lasker 1998).

Here, we document the temporal and spatial dynamics of zooxanthellae within the Caribbean octocoral Plexaura kuna. As an adult, P. kuna hosts only zooxanthellae belonging to Clade B (Rowan \& Powers 1991, Goulet \& Coffroth 2003). Using multilocus DNA fingerprinting, we determined the zooxanthella genotypic identity in individual $P$. kuna colonies temporally for up to a decade. Also, P. kuna is highly clonal, frequently propagating asexually via fragmentation (Coffroth \& Lasker 1998). The presence of genetically identical host colonies of varying ages allowed us to extend the temporal analysis of within host zooxanthella dynamics across the decades of colony growth and propagation. Spatially, we sampled clonemates and determined the zooxanthella genotype(s) in a host following a reciprocal transplant experiment.

\section{MATERIALS AND METHODS}

Temporal comparisons of zooxanthella genotypes. First, we repeatedly sampled 21 individual Plexaura kuna colonies from 3 reefs in the San Blas Islands, Panama, over a maximum 10 yr period (1989 to 1998) (Table 1). Second, we compared zooxanthella genotypes in $P$. kuna clonemates from 12 genetically distinct $P$. kuna host clones. The $P$. kuna clones occurred

Table 1. Plexaura kuna. The similarity index (SI) of zooxanthella (Z) and host (H) DNA fingerprints from the same $P$. kuna colony over a maximum $10 \mathrm{yr}$ period. For $\mathrm{Z}$ versus $\mathrm{Z}$ comparisons between years, the DNA fingerprints of zooxanthellae from all samples of a given colony were scored against each other. For $\mathrm{Z}$ versus $\mathrm{H}$ comparisons, the zooxanthella fingerprints were scored against the host. Samples were collected in July or August 1989, 1991, 1993, 1994, 1995 and 1996; January and September 1997; and in April 1998. Colonies were sampled at Korbiski (K), Sail Rock (S) and

Tiantupo (Ti) reefs in the San Blas Islands, Panama

\begin{tabular}{|llccc|}
\hline $\begin{array}{c}\text { P. kuna } \\
\text { colony }\end{array}$ & Years sampled & $\begin{array}{c}\text { Maximum } \\
\text { yr } \begin{array}{c}\text { between } \\
\text { samples }\end{array}\end{array}$ & SI Z vs Z & SI Z vs H \\
\hline K 522 & $89,91,95,96,98$ & 10 & 1 & 0.16 \\
K 523 & $89,96,98$ & 10 & 1 & 0.43 \\
K 525 & $89,94,96,98$ & 10 & 1 & 0.30 \\
K 940 & $89,91,94,98$ & 10 & 1 & 0.39 \\
S 1 & $91,93,94,95,98$ & 8 & 1 & 0.00 \\
S 11 & $91,93,98$ & 8 & 1 & 0.00 \\
S 26 & 95,98 & 4 & 1 & 0.09 \\
S 58 & 96,98 & 3 & 1 & 0.00 \\
S 63 & 96,98 & 3 & 1 & 0.31 \\
S 68 & 96,98 & 3 & 1 & 0.18 \\
S 73 & 96,98 & 3 & 1 & 0.16 \\
S 79 & 96,98 & 3 & 1 & 0.09 \\
S 84 & 96,98 & 3 & 1 & 0.07 \\
S 87 & 96,98 & 3 & 1 & 0.07 \\
Ti 549 & $93,96,98$ & 6 & 1 & 0.06 \\
Ti 579 & $94,95,96,98$ & 5 & 1 & 0.07 \\
Ti 602 & $95,96,98$ & 4 & 1 & 0.06 \\
Ti 640 & 96,98 & 3 & 1 & 0.06 \\
Ti 647 & 96,98 & 3 & 1 & 0.07 \\
Ti 649 & 96,98 & 3 & 1 & 0.06 \\
Ti 655 & $96,97,97,98$ & 3 & 1 & 0.06 \\
\hline
\end{tabular}


on 3 reefs in the San Blas Islands, Panama: Korbiski reef ( $\mathrm{K}, 2$ clones), Sail Rock Reef ( $\mathrm{S}, 4$ clones), Tiantupo Reef (Ti, 3 clones) and on a reef in the Florida Keys: Three Sisters Reef (TS, 3 clones). The number of clonemates sampled from each clone ranged from 2 to 16 clonemates (Table 2). Samples from Clones D, H and T from Three Sisters Reef included all colonies known to belong to those clones (Coffroth \& Lasker 1998).

Spatial comparisons of zooxanthella genotypes. Since clonemates are exposed to different microhabitats on the same reef, Plexaura kuna clones also provided an environmental comparison. In the TiA and TiB clones on Tiantupo Reef, we found the clonemates that were farthest apart (13 and $22 \mathrm{~m}$, respectively) and sampled all clonemates along the transect between these maximal distances. To determine whether zooxanthellae within small colonies differed from large ones, we measured the height of $P$. kuna colonies (cm) found along the longest axis of the TiA and TiB clones.

To further test for habitat influence on the zooxanthella complement within a host, we conducted a reciprocal transplant experiment on 2 reefs in the San Blas Islands, Panama. We placed transplants in 3 natural habitats for Plexaura kuna, Tiantupo backreef shallow (TiS $<5 \mathrm{~m}$ ), Sail Rock forereef shallow ( $\mathrm{SS}<5 \mathrm{~m}$ ) and Sail Rock forereef deep (SD $>10 \mathrm{~m}$ ). We also placed transplants in 2 extreme habitats where Plexaura kuna is not found (although other octocorals inhabit the area). These were the very deep forereef of Sail Rock (SV $>20 \mathrm{~m}_{1}$ ) and the deep backreef of Tiantupo (TiD

Table 2. Plexaura kuna. The similarity index (SI) of zooxanthella (Z) and host (H) DNA fingerprints obtained from $P$. kuna clones. The DNA fingerprints of zooxanthellae from all sampled clonemates (n) of a clone were scored against each other. For $\mathrm{Z}$ versus $\mathrm{H}$ comparisons, the zooxanthella DNA fingerprints from a particular host were scored against the DNA fingerprint of the host. Colonies were sampled at Korbiski (K), Sail Rock (S) and Tiantupo (Ti) reefs in the San Blas Islands, Panama, and Three Sisters reef (TS) in the Florida Keys. Clones sampled from $\mathrm{K}, \mathrm{Ti}$ and TS reefs occurred in depths $<5 \mathrm{~m}$. From $\mathrm{S}$ reef, Clone sh2 was found in $<5 \mathrm{~m}$ depth, while Clones dp1, dp2 and dp3 occurred between 10 and $15 \mathrm{~m}$

\begin{tabular}{|llrcc|}
\hline Reef & Clone & $\mathrm{n}$ & $\mathrm{SI}$ of Z vs Z & SI of Z vs H \\
\hline $\mathrm{K}$ & $\mathrm{KA}$ & 13 & 1 & 0.16 \\
& $\mathrm{KC}$ & 4 & 1 & 0.30 \\
$\mathrm{~S}$ & $\mathrm{sh} 2$ & 2 & 1 & 0.31 \\
& $\mathrm{dp} 1$ & 2 & 1 & 0.16 \\
& $\mathrm{dp} 2$ & 3 & 1 & 0.09 \\
& $\mathrm{dp} 3$ & 3 & 1 & 0.07 \\
$\mathrm{Ti}$ & $\mathrm{TiA}$ & 16 & 1 & 0.07 \\
& $\mathrm{TiB}$ & 13 & 1 & 0.06 \\
$\mathrm{TS}$ & $\mathrm{TiC}$ & 9 & 1 & 0.06 \\
& $\mathrm{D}$ & 4 & 1 & 0.00 \\
& $\mathrm{H}$ & 2 & 1 & 0.20 \\
& $\mathrm{~T}$ & 2 & 1 & 0.18 \\
\hline
\end{tabular}

$>10 \mathrm{~m})$. From the natural habitats, we sampled a minimum of 3 colonies, 1 each from $3 P$. kuna clones. In addition, 2 colonies were sampled from 1 TiS clone (TiC) and $1 \mathrm{SD}$ clone (Si dp3). We placed a $15 \mathrm{~cm}$ branch fragment from each source site on modified cement flats (Kim \& Lasker 1997), randomly choosing fragments and their position on the flat. Since different areas of a $P$. kuna colony have the same prominent zooxanthella genotype (Goulet \& Coffroth 1997, 2003), all fragments initially had the same prominent zooxanthella genotype. Fragments were transplanted in August 1996 and were sampled in January 1997, September 1997 and finally 20 mo later, in April 1998. To document that zooxanthellae respond to this level of environmental change, zooxanthella density within a $0.5 \mathrm{~cm}$ piece of $P$. kuna tissue, $1.0 \mathrm{~cm}$ from the tip, was counted using a hemocytometer. Six replicate cell counts were conducted. Each source site was analyzed separately. Zooxanthella counts were compared with a 2-way ANOVA (Sokal \& Rohlf 1981).

DNA fingerprinting analysis. DNA extraction followed the protocol of Coffroth et al. (1992). For each host genotype, at least 1 zooxanthella DNA sample was further cleaned by putting the zooxanthella pellet through a 20 and $80 \%$ Percoll step gradient (Stochaj \& Grossman 1997). For DNA fingerprinting, the bacteriophage, M13, was used as a probe in a chemiluminescence hybridization procedure (Boehringer Mannheim) and the bands visualized with Lumi-Phos 480 (Life Codes). Since Percoll-cleaned zooxanthellae were run side by side to the zooxanthella and host lanes of the same Plexaura kuna colony, bands could confidently be assigned to the host or symbiont. We conducted pairwise comparisons of fragment patterns only on samples run on the same gel. DNA fingerprints were scored using bands between 3 and $23 \mathrm{~kb}$, which then had their similarity index (SI) calculated (SI $=2 \times$ No. of shared bands/[No. of bands in Individual A + No. of bands in Individual B]; Lynch 1988). SI ranges from 0, for genetically different individuals (i.e. no bands shared), to 1, for genetically identical individuals (i.e. all bands shared). Genetically different individuals, however, may share some bands due to co-migration and background levels of population band-sharing.

The DNA fingerprinting technique examines the whole genome and provides a composite picture if multiple genotypes are present, detecting the most abundant genotypes. For example, Goulet \& Coffroth (2003) demonstrated that the DNA fingerprinting technique detected a zooxanthella genotype if it constituted $10 \%$ or more of the sample. Those genotypes that may occur in low abundance do not provide enough DNA for detection with this technique. We therefore refer to the genotype visualized in the DNA fingerprint as the prominent zooxanthella genotype. 


\section{RESULTS}

\section{Temporal comparisons of zooxanthella genotypes}

Each genetically distinct host colony displayed a unique zooxanthella DNA fingerprint, termed the prominent genotype (Goulet \& Coffroth 1997, 2003), which did not change throughout the sampling period (Fig. 1, Table 1). The low SI values in the zooxanthella versus host comparisons demonstrate that the DNA fingerprinting technique resolves between zooxanthella and host DNA (Fig. 1, Table 1).

When we compared clonemates within 12 genetically distinct Plexaura kuna clones, we found that, without exception (irrespective of colony size), all clonemates of the same clone exhibited the exact same zooxanthella DNA fingerprint (Fig. 1, Table 2). On the

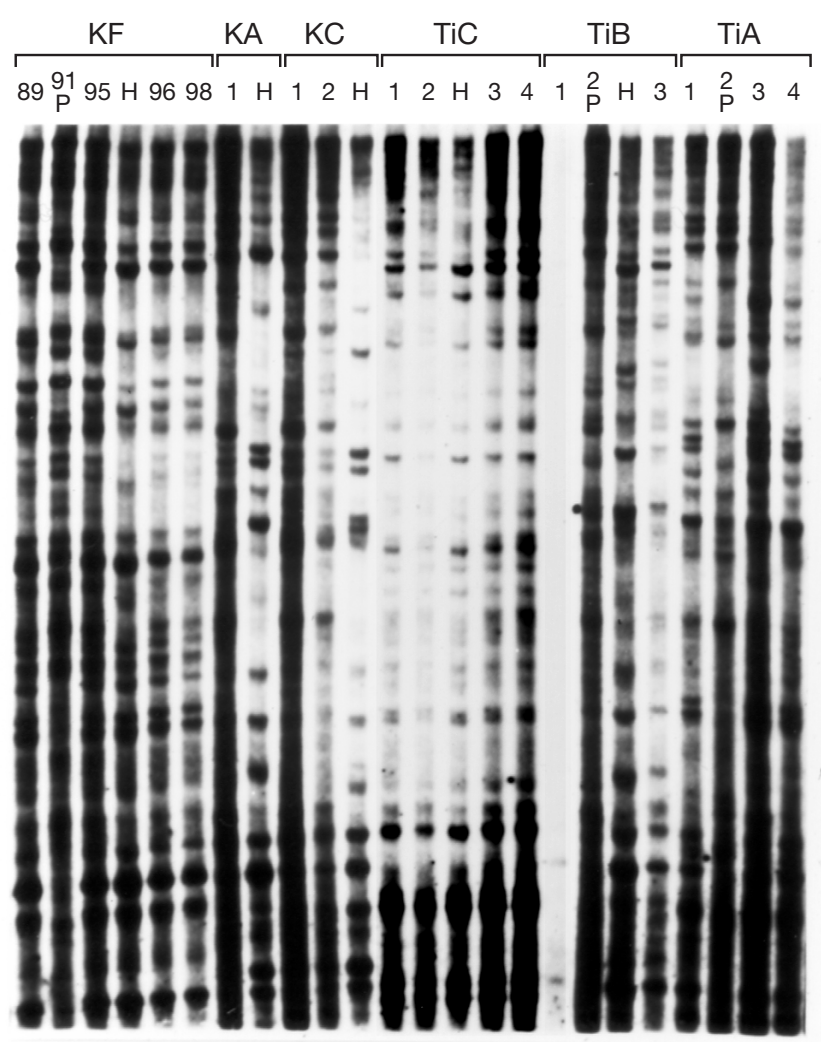

Fig. 1. Plexaura kuna. Autoradiograph of DNA fingerprints of $P$. kuna hosts $(\mathrm{H})$ and their zooxanthellae (all other lanes). Lanes 1 to 6, counting from left to right, are of zooxanthellae and the host colony (Lane 4) belonging to Clone KF sampled repeatedly from 1989 to 1998 as follows: July or August 1989, 1991, 1995 and 1996; and April 1998. Lanes 7, 8 and 9 to 11 are of zooxanthellae and hosts from Clones $\mathrm{KA}$ and $\mathrm{KC}$, respectively, from Korbiski Reef. Lanes 12 to 16,17 to 20 and 21 to 24 are of zooxanthellae and a representative host from clonemates of the clones $\mathrm{TiC}, \mathrm{TiB}$ and $\mathrm{TiA}$, respectively, all from Tiantupo Reef. Zooxanthella samples further cleaned with a percoll step gradient are denoted by a P
Table 3. Plexaura kuna. Comparison of zooxanthella DNA fingerprints of genetically distinct $P$. kuna colonies. Pairwise comparisons were only performed on samples run side by side on the same DNA fingerprinting gel. Colonies were sampled at Korbiski (K), Sail Rock (S) and Tiantupo (Ti) reefs in the San Blas Islands, Panama, and Three Sisters reef (TS) in the Florida Keys. SI: similarity index

\begin{tabular}{|lcc|}
\hline Reef & Clones compared & SI \\
\hline K & KA vs KC & 0.31 \\
& KA vs KF & 0.21 \\
& KB vs KC & 0.05 \\
& KC vs KD & 0.29 \\
S & sh1 vs sh2 & 0.48 \\
& sh2 vs sh3 & 0.15 \\
& dp1 vs dp2 & 0.11 \\
& dp2 vs dp3 & 0.24 \\
& 1 vs 11 & 0.28 \\
Ti & 11 vs 26 & 0.14 \\
& TiA vs TiB & 0.28 \\
& TiB vs TiC & 0.55 \\
K vs Ti & TiC vs TiA & 0.27 \\
TS & KC vs TiC & 0.24 \\
& & D vs H \\
Ti vs TS & H vs T & 0.19 \\
& TiB vs T & 0.10 \\
\hline
\end{tabular}

other hand, zooxanthella DNA fingerprints did vary between different $P$. kuna clones (Fig. 1, Table 3).

\section{Spatial comparisons of zooxanthella genotypes}

Some of the sampled clonemates of Plexaura kuna clones were found on the same reef in habitats varying in depth and exposure to currents and wave action, and separated by as much as $75 \mathrm{~m}$ (Coffroth \& Lasker 1998). Despite these environmental differences, all clonemates from a given clone shared the same unique zooxanthella DNA profile (Table 2). When P. kuna fragments were transplanted to different reefs and different depths, transplants exhibited changes in zooxanthella density and branch morphology. Fragments from shallow depths, transplanted to another reef and/or deeper water, had significantly fewer zooxanthellae per $\mathrm{cm}^{2}$ compared to the control transplant maintained at the original location in shallow water (Fisher's protected least significant differences [PLSD], $p<0.05$; Fig. 2). Fragments of shallow forereef colonies transplanted to backreef habitats (shallow and deep), as well as fragments transplanted from shallow to deep in the backreef habitat, were significantly smaller in diameter after 20 mo (Fisher's PLSD, p < 0.05). The 
zooxanthella DNA fingerprints however, were identical across all 5 transplants of a given colony and identical to the zooxanthella DNA fingerprint from the original colony, both at the start, middle and end of the experiment. Thus, exposing the host to different environments, including different reefs and depths, did not alter the prominent zooxanthella genotype.

\section{DISCUSSION}

In a mutualistic association, a host and its symbiont associate, to the benefit of both partners. Changing needs, occurring over the host's lifetime or because of environmental change, may trigger symbiont switching. Our findings demonstrate a remarkable stability of the mutualism between the Caribbean octocoral Plexaura kuna and its zooxanthellae. A P. kuna colony exhibited the same prominent zooxanthella genotype

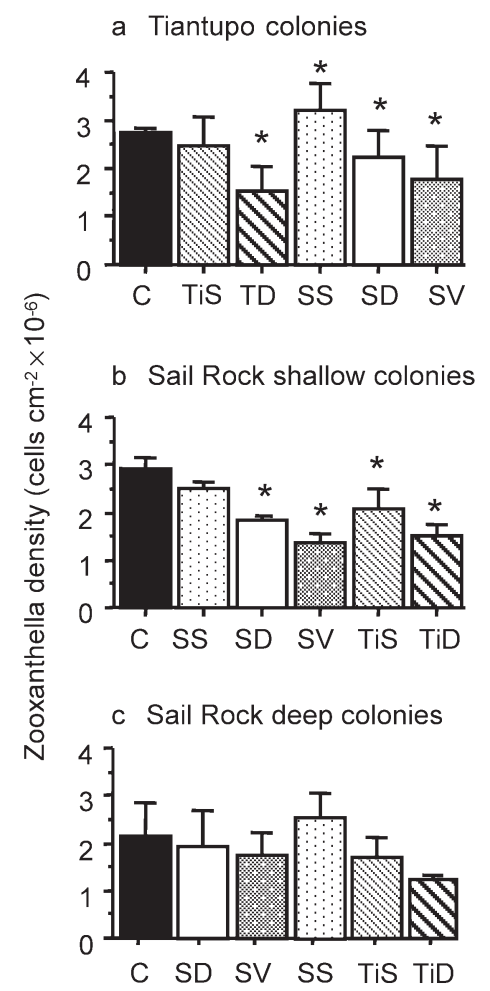

Fig. 2. Plexaura kuna. Zooxanthella density of $P$. kuna fragments transplanted to various depths within and among reefs. Each bar represents the mean + SD of 3 colonies transplanted from the source site $(\mathrm{a}, \mathrm{b}$ or $\mathrm{c})$ to a transplanted site $(\mathrm{Ti}=$ Tiantupo; $\mathrm{S}=$ Sail Rock) of different depths (identified by following letters after site abbreviations: $\mathrm{S}=$ shallow; $\mathrm{D}=$ deep; $\mathrm{V}=$ very deep) sampled 20 mo after the transplant. $\mathrm{C}=$ the original colonies. ${ }^{*}$ : a significant difference $(p<0.0001)$ between zooxanthella numbers in the transplant at the original site and the other treatments, as determined by a Fisher's PLSD post-hoc test (Sokal \& Rohlf 1981) for as long as 10 yr. During this 10 yr period, elevated water temperatures occurred in 1995 (CARICOMP 1997), causing several corals to bleach (Rowan et al. 1997). In $P$. kuna, a reduction in zooxanthella numbers of $>95 \%$ results in only a slight lightening of the colony (S. R. Santos \& M. A. Coffroth unpubl. data). Therefore, although $P$. kuna can lose algae, visibly it does not look bleached. Even with a potential reduction in zooxanthella numbers during the elevated temperature episode, the 8 colonies sampled before and after 1995 retained their unique zooxanthella DNA fingerprint. Since we did not sample immediately after the rise in temperature, zooxanthella turnover could have occurred and then reverted to the original prominent zooxanthella genotype. This scenario is not probable because a $P$. kuna colony sampled at short intervals (6 mo) exhibited the same zooxanthella DNA fingerprint. Therefore, in long-term monitoring of zooxanthella genotypes in the same individual host colony, the zooxanthella prominent genotype did not change.

The clonal nature of Plexaura kuna allowed us to further extend our temporal comparison, following the symbiosis potentially throughout a host genet's life. Since different areas of a $P$. kuna colony have the same prominent zooxanthella genotype (Goulet \& Coffroth 2003), a branch broken from a colony (i.e. a new clone) initially would have the same prominent zooxanthella genotype as the parent colony. Small-sized P. kuna clonemates could have different energetic demands and allocations that might favor different symbionts. Different $P$. kuna clonemates, situated in different microhabitats, could have different requirements from their symbionts. If different host-symbiont genotypic combinations could occur, we would expect to see them in some $P$. kuna clonemates. Yet, when comparing $P$. kuna clonemates, ranging in size and in microhabitat on the same reef, the prominent zooxanthella genotype within a $P$. kuna clone was always identical between clonemates.

The zooxanthella genotypic stability exhibited in Plexaura kuna cannot be attributed to a lack of zooxanthella variability in zooxanthella populations at large, since zooxanthella DNA fingerprints differed between $P$. kuna clones (Table 3). Furthermore, other cnidarian species on the same reefs harbor multiple zooxanthella clades (Rowan \& Knowlton 1995, Rowan et al. 1997, Baker 2001, Toller et al. 2001a), demonstrating the diversity of zooxanthella clades available on these reefs. On a given reef, the host-symbiont combination may be optimal given the zooxanthella genotypes available. In addition, the environmental variability on a single reef may not be great enough to select among symbiont genotypes. The transplant experiment, however, exposed $P$. kuna to new habitats and environmental conditions. 
The transplant experiment reported here placed Plexaura kuna colonies on different reefs at different depths, including an extreme depth, where P. kuna is not normally found, thereby potentially exposing $P$. kuna to a new pool of zooxanthellae. Transplanting $P$. kuna did affect features of the host, as seen by a morphological change and, in some cases, affected zooxanthella densities, demonstrating both a host and symbiont response to the treatments and the success of the transplant experiment. The zooxanthella DNA fingerprints however, were identical across all 5 transplants of a given colony and to the zooxanthella DNA fingerprint from the original colony. Furthermore, since the transplants were sampled throughout the year, August, January, September and April, no seasonal change in zooxanthella genotype was observed. The transplant experiment demonstrated that not only temporally but spatially exposing the host to different environments, including different reefs and depths, did not alter the prominent zooxanthella genotype.

The stasis of the prominent zooxanthella genotype implies the presence of a mechanism that maintains a specific symbiont, once it has entered the host. Primary polyps of Plexaura kuna can initially acquire multiple zooxanthella genotypes, including zooxanthellae belonging to different clades (Coffroth et al. 2001). After initial acquisition, however, only Clade B zooxanthellae were detected in all $P$. kuna colonies sampled (Goulet 1999, Goulet \& Coffroth 2003), even among colonies as small as $0.5 \mathrm{~cm}$ in height (Coffroth et al. 2001). The prominent zooxanthella genotype may competitively exclude other genotypes attempting to enter the association. Fitt (1985) found that zooxanthella strains differed in their growth rate, and in a host infected with 2 strains, faster growing strains outgrew slower growing strains. Schoenberg \& Trench (1976) demonstrated that under normal conditions, resident zooxanthella strains grew faster in their host compared to introduced, foreign zooxanthella strains. Alternatively, the host may be the one to selectively retain its symbionts. At present, there are no data to evaluate whether either the host or symbiont is maintaining control over the symbiosis genotypic composition.

The lack of symbiont change is consistent with theories explaining the establishment of zooxanthella populations in hosts with horizontal transmission (Wilcox 1997, Genkai-Kato \& Yamamura 1999). In systems where symbionts are acquired every generation, benevolent symbionts (those that are not detrimental to the host) will remain if symbionts are acquired only once in a life cycle and the acquisition stage is sensitive to selection. 'Selfish symbionts', symbionts that increase their own growth at the expense of the host, will be selected against (Wilcox 1997). Limiting symbiont genotypes within a host also avoids competition among symbiont genotypes that may lower host fitness (Frank 1996).

Using multilocus DNA fingerprinting, we demonstrated that in the octocoral Plexaura kuna, the zooxanthella genotypes are stable both temporally and spatially. If the persistence of a fixed host-symbiont pairing seen in the $P$. kuna-zooxanthella symbiosis is representative of the other $84.4 \%$ of cnidarian mutualisms that normally harbor a single zooxanthella clade, then our findings have implications for predictions of the response of reef corals to global warming and for reef conservation measures. For example, the symbiosis stability may indicate that reefs are more resilient to global warming than predicted. On the other hand, and of more concern, this stability may represent the inability of the host to switch its zooxanthellae. If this were the case, then a bleached coral could only recuperate through re-population by the remaining algal population and not by acquiring zooxanthellae from the environment. The question then becomes not whether symbiont switching is possible, but how far existing symbiotic combinations can be pushed before symbiosis de-coupling occurs. Determining the degree of elasticity of a symbiosis will then aid in predicting survival of specific host-symbiont combinations during environmental changes brought on by global warming or direct human influence.

Acknowledgements. We thank E. Beiring, A. Dwileski-Pfister, D. Goulet, N. Knowlton, H. Lasker, R. Rowan, S. Santos, T. Swain, A. Verde, the Kuna Indians and the Republic of Panama. The comments of R. Buchholz, D. Goulet, T. Threlkeld and anonymous reviewers greatly improved the manuscript. This work was supported by: Lerner Gray Fund for Marine Research; Houston Underwater Club; Mark Diamond Research Fund; PADI Foundation; Sigma Xi Society; and a Smithsonian Tropical Research Institute, short-term fellowship to T.L.G.; and the National Undersea Research Center at University of North Carolina at Wilmington and National Science Foundation OCE-9530057 to M.A.C.

\section{LITERATURE CITED}

Baillie BK, Monje V, Silvestre V, Sison M, Belda-Baillie CA (1998) Allozyme electrophoresis as a tool for distinguishing different zooxanthellae symbiotic with giant clams. Proc R Soc Lond Ser B 265:1949-1956

Baillie BK, Belda BCA, Maruyama T (2000a) Conspecificity and Indo-Pacific distribution of Symbiodinium genotypes (Dinophyceae) from giant clams. J Phycol 36:1153-1161

Baillie BK, Belda BCA, Silvestre V, Sison M, Gomez AV, Gomez ED, Monje V (2000b) Genetic variation in Symbiodinium isolates from giant clams based on randomamplified-polymorphic DNA (RAPD) patterns. Mar Biol 136:829-836

Baker AC (1999) The symbiosis ecology of reef-building corals. PhD thesis, University of Miami, Coral Gables, FL

Baker AC (2001) Reef corals bleach to survive change. Nature 411:765-766 
Baker AC, Rowan R (1997) Diversity of symbiotic dinoflagellates (zooxanthellae) in scleractinian corals of the Caribbean and Eastern Pacific. Proc 8th Int Coral Reef Symp, Panama 2:1301-1306

Billinghurst Z, Douglas AE, Trapido-Rosenthal HG (1997) On the genetic diversity of the symbiosis between the coral Montastraea cavernosa and zooxanthellae in Bermuda. Proc 8th Int Coral Reef Symp, Panama 2:1291-1294

Buddemeier RW, Fautin DG (1993) Coral bleaching as an adaptive mechanism. BioScience 43:320-326

Bythell JC, Douglas AE, Sharp VA, Searle JB, Brown BE (1997) Algal genotype and photoacclimatory responses of the symbiotic alga Symbiodinium in natural populations of the sea anemone Anemonia viridis. Proc R Soc Lond Ser B 264:1277-1282

CARICOMP (Caribbean Coastal Marine Productivity) (1997) Studies on Caribbean coral bleaching, 1995. Proc 8th Int Coral Reef Symp, Panama 1:673-678

Carlos AA, Baillie BK, Kawachi M, Maruyama T (1999) Phylogenetic position of Symbiodinium (Dinophyceae) isolates from tridacnids (Bivalvia), cardiids (Bivalvia), a sponge (Porifera), a soft coral (Anthozoa), and a free-living strain. J Phycol 35:1054-1062

Carlos A, Baillie B, Maruyama T (2000) Diversity of dinoflagellate symbionts (zooxanthellae) in a host individual. Mar Ecol Prog Ser 195:93-100

Coffroth MA, Lasker HR (1998) Population structure of a clonal gorgonian coral: the interplay between clonal reproduction and disturbance. Evolution 52:316-330

Coffroth MA, Lasker HR, Diamond ME, Bruenn JA, Bermingham E (1992) DNA fingerprints of a gorgonian coral: a method for detecting clonal structure in a vegetative species. Mar Biol 114:317-325

Coffroth MA, Santos SR, Goulet TL (2001) Early ontogenetic expression of specificity in a cnidarian-algal symbiosis. Mar Ecol Prog Ser 222:85-96

Darius HT, Dauga C, Grimont PAD, Chungue E, Martin PMV (1998) Diversity in symbiotic dinoflagellates (Pyrrhophyta) from 7 scleractinian coral species: restriction enzyme analysis of small subunit ribosomal RNA genes. J Eukaryot Microbiol 45:619-627

Diekmann OE, Bak RPM, Tonk L, Stam WT, Olsen JL (2002) No habitat correlation of zooxanthellae in the coral genus Madracis on a Curaçao reef. Mar Ecol Prog Ser 227: 221-232

Fitt WK (1985) Effect of different strains on the zooxanthella Symbiodinium microadriaticum on growth and survival of their coelenterate and molluscan hosts. Proc 5th Int Coral Reef Congr, Tahiti 6:131-136

Frank SA (1996) Host-symbiont conflict over the mixing of symbiotic lineages. Proc R Soc Lond Ser B 263:339-344

Genkai-Kato M, Yamamura N (1999) Evolution of mutualistic symbiosis without vertical transmission. Theor Popul Biol 55:309-323

Glynn PW (1996) Coral reef bleaching: facts, hypotheses and implications. Global Change Biol 2:495-509

Goulet TL (1999) Temporal and spatial stability of zooxanthellae in octocorals. PhD thesis, State University of New York at Buffalo

Goulet TL, Coffroth MA (1997) A within colony comparison of zooxanthellae genotypes in the Caribbean gorgonian Plexaura kuna. Proc 8th Int Coral Reef Symp, Panama 2: 1331-1334

Goulet TL, Coffroth MA (2003) Genetic composition of zooxanthellae between and within colonnies of the octocoral Plexaura kuna based on small subunit rDNA and multilocus DNA fingerprinting. Mar Biol 142:233-239
Hill M, Wilcox T (1998) Unusual mode of symbiont repopulation after bleaching in Anthosigmella varians: acquisition of different zooxanthellae strains. Symbiosis 25:279-289

Hoegh-Guldberg O, Jones RJ, Ward S, Loh W (2002) Ecology: is coral bleaching really adaptive? Nature 415:601-602

Jeffreys AJ, Wilson V, Thein SL (1985a) Hypervariable 'minisatellite' regions in human DNA. Nature 314:67-73

Jeffreys AJ, Wilson V, Thein SL (1985b) Individual-specific 'fingerprints' of human DNA. Nature 316:76-79

Kim K, Lasker HR (1997) Flow-mediated resource competition in the suspension feeding gorgonian Plexaura homomalla (Esper). J Exp Mar Biol Ecol 215:49-64

LaJeunesse TC (2001) Investigating the biodiversity, ecology, and phylogeny of endosymbiotic dinoflagellates in the genus Symbiodinium using the ITS region: in search of a 'species' level marker. J Phycol 37:866-880

LaJeunesse TC (2002) Diversity and community structure of symbiotic dinoflagellates from Caribbean coral reefs. Mar Biol 141:387-400

Loh WKW, Loi T, Carter D, Hoegh-Guldberg O (2001) Genetic variability of the symbiotic dinoflagellates from the wide ranging coral species Seriatopora hystrix and Acropora longicyathus in the Indo-West Pacific. Mar Ecol Prog Ser 222:97-107

Lynch M (1988) Estimation of relatedness by DNA fingerprinting. Mol Biol Evol 5:584-599

Muscatine L, Porter J (1977) Reef corals: mutualistic symbioses adapted to nutrient-poor environments. BioScience $27: 454-460$

Rodriguez-Lanetty M, Loh W, Carter D, Hoegh-Guldberg O (2001) Latitudinal variability in symbiont specificity within the widespread scleractinian coral Plesiastrea versipora. Mar Biol 138:1175-1181

Rosenberg E, Ben-Haim Y (2002) Microbial diseases of corals and global warming. Environ Microbiol 4:318-326

Rowan R (1991) Molecular systematics of symbiotic algae. J Phycol 27:661-666

Rowan R, Knowlton N (1995) Intraspecific diversity and ecological zonation in coral-algal symbiosis. Proc Natl Acad Sci USA 92:2850-2853

Rowan R, Powers DA (1991) A molecular genetic classification of zooxanthellae and the evolution of animal-algal symbiosis. Science 251:1348-1351

Rowan R, Powers DA (1992) Ribosomal RNA sequences and the diversity of symbiotic dinoflagellates (zooxanthellae). Proc Natl Acad Sci USA 89:3639-3643

Rowan R, Knowlton N, Baker A, Jara J (1997) Landscape ecology of algal symbionts creates variation in episodes of coral bleaching. Nature 388:265-269

Santos SR, Taylor DJ, Coffroth MA (2001) Genetic comparisons of freshly isolated versus cultured symbiotic dinoflagellates: implications for extrapolating to the intact symbiosis. J Phycol 37:900-912

Santos SR, Taylor DJ, Kinzie RAI, Hidaka M, Sakai K, Coffroth MA (2002) Molecular phylogeny of symbiotic dinoflagellates inferred from partial chloroplast large subunit (23S)rDNA sequences. Mol Phylogenet Evol 23:97-111

Schoenberg DA, Trench RK (1976) Specificity of symbioses between marine cnidarians and zooxanthellae. In: Mackie GO (ed) Coelenterate ecology and behavior. Plenum Press, New York, p 423-432

Sokal RR, Rohlf FJ (1981) Biometry, 2nd edn. WH Freeman, San Francisco

Stochaj WR, Grossman AR (1997) Differences in the protein profiles of cultured and endosymbiotic Symbiodinium sp. (Pyrrophyta) from the anemone Aiptasia pallida (Anthozoa). J Phycol 33:44-53 
Toller WW, Rowan R, Knowlton N (2001a) Zooxanthellae of the Montastraea annularis species complex: patterns of distribution of 4 taxa of Symbiodinium on different reefs and across depths. Biol Bull (Woods Hole) 201: 348-359

Toller WW, Rowan R, Knowlton N (2001b) Repopulation of zooxanthellae in the Caribbean corals Montastaea annularis and $M$. faveolata following experimental and disease-associated bleaching. Biol Bull (Woods Hole) 201: $360-373$

Editorial responsibility: Otto Kinne (Editor),

Oldendorf/Luhe, Germany van Oppen MJH, Palstra FP, Piquet AMT, Miller DJ (2001) Patterns of coral-dinoflagellate associations in Acropora: significance of local availability and physiology of Symbiodinium strains and host-symbiont selectivity. Proc R Soc Lond Ser B 268:1759-1767

Ware JR, Fautin DG, Buddemeier RW (1996) Patterns of coral bleaching: modeling the adaptive bleaching hypothesis. Ecol Model 84:199-214

Wilcox TP (1997) The evolution of algal-invertebrate symbioses. PhD thesis, University of Houston, TX

Submitted: November 6, 2002; Accepted: November 21, 2002 Proofs received from author(s): March 10, 2003 